\title{
Persistence of herpesvirus of eel Herpesvirus anguillae in farmed European eel Anguilla anguilla
}

\author{
A. P. van Nieuwstadt*, S. G. Dijkstra, O. L. M. Haenen \\ Fish Diseases Laboratory, ID-Lelystad Institute for Animal Science and Health, PO Box 65, 8200 A B Lelystad, The Netherlands
}

\begin{abstract}
Herpesvirus of eel Herpesvirus anguillae (HVA) was isolated repeatedly from farmed eel of an outwardly healthy stock, but virus isolation was much greater in an experimental group of fish that were injected with dexamethasone. The results suggest that HVA can establish a latent infection in eel. Previous exposure of these eels to HVA virus was shown by detection of HVA-specific antibodies. These eels did not show clinical signs after a secondary infection with HVA. Tracing of seropositive eel stocks, which had previous contact with HVA, and of HVA carrier fish can be useful to control disease outbreaks due to HVA infection.
\end{abstract}

KEY WORDS: Herpesvirus · Eel · Latency · Dexamethasone

\section{INTRODUCTION}

Since 1996 when an eel kidney cell line (EK-1 cells) was introduced for virus isolation in our fish disease laboratory, herpesvirus of eel Herpesvirus anguillae (HVA) has been isolated from 18 disease outbreaks in farmed eel in The Netherlands (Davidse et al. 1999). The disease was manifested by dermal haemorrhagic lesions mainly in the pectoral fin and opercular regions, and by congestion and destruction of gill filaments. In later stages of disease haemorrhages extended to the abdominal skin. Similar disease outbreaks were reported from 1993 to 1995 from farmed eel in Japan, where a herpesvirus was isolated (Lee et al. 1999). In this latter study disease was reproduced in smaller eels by intramuscular inoculation of this virus. Virus neutralisation tests showed an antigenic relation of the Dutch and J apanese herpesvirus isolates to the Herpesvirus anguillae reported by Sano et al. (1990).

To study further the pathogenesis of this herpesvirus and to obtain specific pathogen-free fishes for experimental infection, we looked for an eel farm that was free of the infection. Herpesviruses are able to persist for a long time in clinically healthy hosts and to

*E-mail: a.p.k.m.i.vannieuwstadt@id.wag-ur.nl recrudesce if the carrier host is stressed, even in the presence of specific antibodies. Herpes simplex virus is well known in humans, which after a primary infection may become latent in sensory ganglia and may recrudesce by as yet poorly defined stimuli and cause cold sores (Whitley 1996). Also, release of infectious bovine rhinotracheitis virus from apparently healthy cattle or pseudorabies virus from swine can be provoked by the administration of corticosteroids (Sheffy \& Davies 1972, van Oirschot \& Gielkens 1984). Persistence of another herpesvirus of fishes, the channel catfish virus, in asymptomatic adult channel catfish has been shown by virus isolation using immunosuppressive treatment of fishes and co-cultivation of leucocytes with channel catfish ovary cells (Bowser et al. 1985).

In the present study persistence of HVA in cultured eel from an outwardly healthy stock was revealed by virus isolation, and virus shedding was much increased by dexamethasone treatment. Furthermore, we developed a serological test to detect HVA-specific antibodies, and we studied some aspects of the antibody response to HVA infection in eel. Screening of eels for HVA-specific antibodies can reveal previous exposure of cultured eel stocks to HVA. Virus carriers can be expected to be present in stocks with seropositive fishes. 


\section{MATERIALS AND METHODS}

Cells, virus, antiserum. EK-1 cells (Chen et al. 1982) were used in the isolation and propagation of HVA throughout this study. Cells were routinely cultured in sterile plastic flasks in Leibovitz-L15 medium (Life Technologies BV, Breda, The Netherlands) supplemented with $5 \%$ foetal bovine serum, antibiotics and 0.075 to $0.15 \%(\mathrm{w} / \mathrm{v})$ bicarbonate. Cultures were incubated at $26^{\circ} \mathrm{C}$ in a $\mathrm{CO}_{2}$ incubator. The Dutch isolate 500138 of HVA was propagated in EK-1 cells, and virus was concentrated and purified from cell culture medium by centrifugation for $4 \mathrm{~h}$ at $53000 \times \mathrm{g}$ through $25 \%(\mathrm{w} / \mathrm{w})$ sucrose in TEN buffer (10 mM Tris, $150 \mathrm{mM} \mathrm{NaCl}, 1 \mathrm{mM}$ EDTA; $\mathrm{pH}$ 7.4). The virus pellet was resuspended in TE buffer $(10 \mathrm{mM}$ Tris. $\mathrm{HCl}, 1 \mathrm{mM}$ EDTA, $\mathrm{pH}$ 7.4) and virus protein concentration was determined using the BCA (bicinchoninic acid) protein assay with bovine serum albumin as a standard (Pierce, Rockford, IL, USA). To obtain specific antiserum, rabbits were immunised 3 times both intramuscularly and subcutaneously with a dose of $1 \mathrm{mg}$ virus protein in complete or incomplete Freund adjuvans. The rabbit immune serum had a titre of 1:1060 in a virus neutralisation test using $150 \mathrm{TCID}_{50}$ of $\mathrm{HVA}$. The rabbit anti-HVA serum was used to type virus isolates, which showed a cytopathic effect characteristic of HVA.

Fish. Eighty outwardly healthy eels ranging in weight from 150 to $200 \mathrm{~g}$ were purchased from an eel farm. Fishes were kept at $23^{\circ} \mathrm{C}$ in six 200 I glass aquariums half filled with tap water, which was aerated continuously and changed for fresh water each day. Water temperature was recorded each day. Eels were offered a hiding place in these aquariums and were subjected to a $12 / 12 \mathrm{~h}$ light/dark cycle. They were fed at a maintenance level with commercial dry pellet feed. For individual identification of fishes from which blood samples were collected weekly, 26 fishes in 2 aquariums were tagged by scratching their skin.

Experimental design. Eels were placed in 6 aquariums (A to $F$ ) in groups of 13 or 14 eels. First blood samples were collected from the caudal vein from all fishes. The experiment was started on Day 0, which was $4 \mathrm{~d}$ after eels arrived at our institute. Fishes in A quariums $A, B$, and $C$ were untreated controls. Fishes in Aquariums $D, E$, and $F$, which were in a separate hall, were administered dexamethasone (Dexadreson ${ }^{\circledR}$ Intervet Nederland BV) on 5 consecutive days (Days 0 to 4). Each fish was injected intramuscularly and intraperitoneally each day with $400 \mu \mathrm{g}$ dexamethasone dissolved in $1 \mathrm{ml}$ water. This dose was chosen because previous workers had shown that the effective dose of dexamethasone for blocking the hypothalamic- pituitary-interrenal axis in teleost fish lies in the range of 0.1 to $10 \mathrm{\mu g} \mathrm{g}^{-1}$ of body weight (Pickering et al. 1987). During the experiment fishes were examined each day for signs of disease. Three fishes from the experimental group and 3 fishes from the non-treated control group were anaesthetised with $0.1 \%(\mathrm{v} / \mathrm{v})$ 2-phenoxy-ethanol in tap water and slaughtered on Day $0,2,4,7,10,14,17,21$, or 24 . Blood was collected, fishes were dissected, and pieces of liver, spleen, and kidney were removed and pooled for each fish. A $10 \%$ suspension of organ sample pools was prepared in cell culture medium and stored at $-70^{\circ} \mathrm{C}$. Separately, a homogenate of gill tissue was prepared. On Day 30, 13 surviving fishes of the group that had been administered dexamethasone were anaesthetised and inoculated intraperitoneally with $2 \times 10^{8} \mathrm{TCID}_{50}$ of HVA virus in $1 \mathrm{ml}$ of cell culture medium. Thirteen surviving fishes of the non-treated group were inoculated by application of $1 \mathrm{ml}$ containing $2 \times 10^{8} \mathrm{TCID}_{50}$ of HVA on their gills. Blood samples were collected every week. Fishes were slaughtered on Days 63 to 76, i.e., from 33 to $46 d$ after inoculation of the virus. Samples of liver, spleen, kidney, and gill were taken and homogenised for virus isolation. Blood was allowed to clot overnight at room temperature and was centrifuged for $10 \mathrm{~min}$ at $800 \times \mathrm{g}$. Serum was collected and stored at $-20^{\circ} \mathrm{C}$ until tested for antibodies specific for HVA.

Virus isolation. Organ sample pools were thawed and centrifuged for $10 \mathrm{~min}$ at $2000 \times \mathrm{g}$ to remove tissue debris. The virus containing supernatant was filtered through a $0.45 \mu \mathrm{m}$ filter and inoculated on a monolayer of EK-1 cells in 6-well plates (Greiner; TC-plate 6 well, Cat. number 657160). After 1 to $2 \mathrm{~h}$ virus adsorption, the inoculum was changed for fresh cell culture medium. Cell cultures were incubated at $26^{\circ} \mathrm{C}$ and were examined over 5 to $6 \mathrm{~d}$ for cytopathic effects. Further passages were undertaken when results were negative or not conclusive. Positive isolations were recognised by a characteristic cytopathic effect and were confirmed as a herpesvirus by electron microscopy. Further identification was by a virus neutralisation test using rabbit immune serum specific for HVA.

HVA antibodies in eel sera. An indirect ELISA was used for detection of HVA antibodies in eel sera. Ninety 6-well microtitration plates (Greiner; Cat. number 655092) were coated overnight at $20^{\circ} \mathrm{C}$ with a dilution of purified HVA (40 ng virus protein well ${ }^{-1}$ ) in $0.05 \mathrm{M}$ carbonate-bicarbonate buffer, $\mathrm{pH}$ 9.6. Eel sera diluted 1:100 in ELISA buffer were preheated for $30 \mathrm{~min}$ at $45^{\circ} \mathrm{C}$ and were incubated on the virus coating. Antibodies bound to HVA were detected by successive incubation with a monoclonal antibody specific for the heavy chain of eel immunoglobulin (a 1:30 dilution of cell culture medium of hybridoma WEI-1 in 
ELISA buffer; van der Heijden et al. 1995) and peroxidase conjugated antibody specific for mouse immunoglobulin (a 1:500 dilution of rabbit anti-mouse serum conjugated to peroxidase; Dakopatts, Denmark, Cat. number P161). 3,3 ', 5, 5'-Tetramethylbenzidine in $0.1 \mathrm{M}$ sodium citrate-acetate buffer, $\mathrm{pH} 6$, with $0.005 \%$ hydrogen peroxide was used as a chromogen/substrate. The enzymatic reaction was stopped with $0.5 \mathrm{M} \mathrm{H}_{2} \mathrm{SO}_{4}$ and optical density at $450 \mathrm{~nm}$ $\left(O D_{450}\right)$ was measured. ELISA buffer was phosphate-buffered saline (10.8 mM phosphate, $137 \mathrm{mM} \mathrm{NaCl}, 2.7 \mathrm{mM} \mathrm{KCl}, \mathrm{pH}$ 7.2) supplemented with $10 \%$ foetal bovine serum, $2 \%$ (w/v) $\mathrm{NaCl}$, and $0.05 \%(\mathrm{w} / \mathrm{v})$ Tween-80. Dilutions of eel serum, monoclonal antibody, and anti-mouse conjugate were added in a volume of $100 \mu \mathrm{l}$ per well and incubated for 1 to $2 \mathrm{~h}$ at $20^{\circ} \mathrm{C}$. Microtitration plates were washed between incubation steps with $0.05 \%(\mathrm{w} / \mathrm{v})$ Tween-80 in ultrapure water (Millipore). All assays included a test of 3-fold serial dilutions of a pool of sera of eels that had been immunised with HVA. All sera were tested in duplicate and the mean $\mathrm{OD}_{450}$ was calculated. Concentrations of HVA antibodies in eel sera were compared using sera that had been examined in 1 test.

\section{RESULTS}

\section{Effect of dexamethasone}

No clinical signs from dexamethasone injections were observed, and no clinical signs were observed after intraperitoneal or gill inoculation of eels with HVA.

\section{Virus isolation}

No virus was isolated from 6 eels that were slaughtered on Day 0. However, fishes were carriers of herpesvirus. In the control group virus shedding was observed in 6 fishes (Table 1). Virus was first isolated from 2 fishes on Day 7, which was $11 \mathrm{~d}$ after fishes were placed in aquariums at our institute. Herpesvirus was isolated from the gills or from the liver-spleenkidney organ pool. In the experimental group virus shedding was observed in 11 fishes from Days 2 to 14 and in all fishes that were slaughtered on Days 4, 7, and 10. In 5 fishes herpesvirus was isolated from the gills and from the pool of internal organs. No herpesvirus was isolated from eels that were slaughtered from 33 to $46 \mathrm{~d}$ after intraperitoneal or gill inoculation
Table 1. Herpesvirus anguillae (HVA) isolation from eels after dexamethasone injection. Eels from the experimental group were injected intramuscularly and intraperitoneally with $400 \mu \mathrm{g}$ dexamethasone on Days $0,1,2,3$, and 4 . Eels of the control group were not injected. Three fishes from each group (numbered 1st, 2nd, and 3rd) were dissected on each day as indicated, and gills and a liver-spleenkidney organ pool of each fish were tested by virus isolation. In total, 27 fishes of each group were tested. +: herpesvirus was isolated; -: virus isolation was negative

\begin{tabular}{|c|c|c|c|c|c|c|c|}
\hline \multicolumn{2}{|c|}{$\begin{array}{l}\text { Post treat- Virus isolation } \\
\text { ment day } \quad \text { from }\end{array}$} & \multicolumn{3}{|c|}{$\begin{array}{l}\text { Control group } \\
\text { 1st 2nd 3rd }\end{array}$} & \multicolumn{3}{|c|}{ Experimental group } \\
\hline \multirow[t]{2}{*}{0} & Gill & - & - & - & - & - & - \\
\hline & Liver, spleen, kidney & - & - & - & - & - & - \\
\hline \multirow[t]{2}{*}{2} & Gill & - & - & - & - & + & - \\
\hline & Liver, spleen, kidney & - & - & - & - & + & - \\
\hline \multirow[t]{2}{*}{4} & Gill & - & - & - & + & + & - \\
\hline & Liver, spleen, kidney & - & - & - & - & - & + \\
\hline \multirow[t]{2}{*}{7} & Gill & + & - & + & + & + & + \\
\hline & Liver, spleen, kidney & - & - & - & + & - & + \\
\hline \multirow[t]{2}{*}{10} & Gill & - & - & - & + & + & + \\
\hline & Liver, spleen, kidney & + & - & - & + & + & - \\
\hline \multirow[t]{2}{*}{14} & Gill & + & - & - & - & - & - \\
\hline & Liver, spleen, kidney & - & - & + & - & + & - \\
\hline \multirow[t]{2}{*}{17} & Gill & - & - & - & - & - & - \\
\hline & Liver, spleen, kidney & - & - & - & - & - & - \\
\hline \multirow[t]{2}{*}{21} & Gill & + & - & - & - & - & - \\
\hline & Liver, spleen, kidney & - & - & - & - & - & - \\
\hline \multirow[t]{2}{*}{24} & Gill & - & - & - & - & - & - \\
\hline & Liver, spleen, kidney & - & - & - & - & - & - \\
\hline
\end{tabular}

of HVA. Six of the 22 herpesvirus isolates were further typed by a virus neutralisation test and were identified as Herpesvirus anguillae.

\section{Serology}

In all eels positive ELISA results were observed in the first blood samples that were taken when fishes arrived at our institute. Results of a random sample of 26 fishes are shown in Fig. 1. These results indicate that fishes had antibodies specific for HVA and had already been exposed to HVA at the eel farm before we started our experiment. No increase of specific antibodies after recrudescence of HVA, spontaneously or induced by dexamethasone treatment, was observed.

However, an antibody response after fishes were inoculated with HVA was observed. Fig. 2 shows the antibody response of 7 eels from the experimental dexamethasone-treated group during the $5 \mathrm{wk}$ after fishes had been inoculated intraperitoneally with $2 \times$ $10^{8} \mathrm{TCID}_{50}$ of HVA on Day 30 of this experiment. Using 


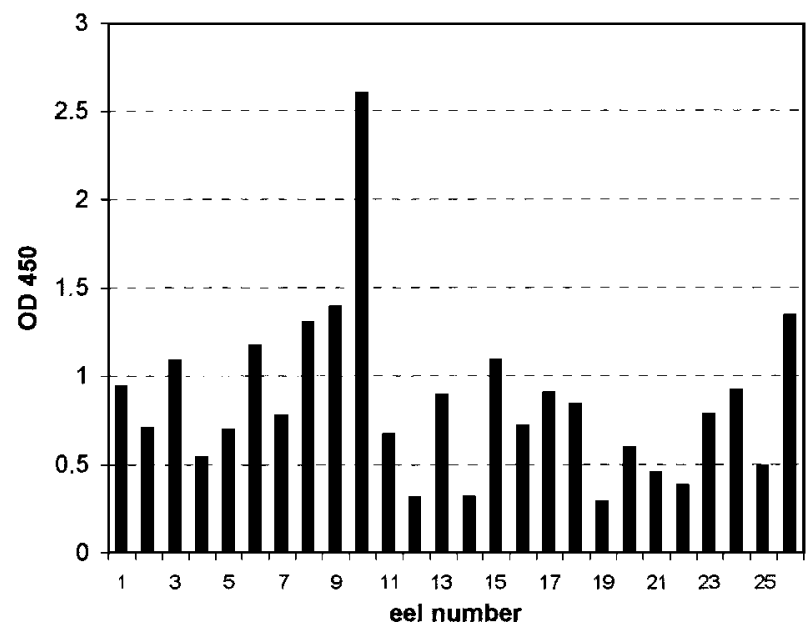

Fig. 1. Optical density at $450 \mathrm{~nm}\left(O D_{450}\right)$ of $1: 100$ serum dilutions in an ELISA for Herpesvirus anguillae (HVA) antibodies in 26 farmed eels sampled at random from an outwardly healthy stock before the experiment was started

the ELISA, low $O D_{450}$ values were measured in blood samples collected $5 \mathrm{~d}$ before and $1 \mathrm{~d}$ after inoculation of HVA. An increase of the $\mathrm{OD}_{450}$ values in sera collected on Day 8 after inoculation was observed, indicating a rise of specific antibodies. A similar increase of specific antibodies was observed in 5 other fishes that were inoculated intraperitoneally and in 7 of 13 fishes that were inoculated by application of HVA on the gills.

\section{DISCUSSION}

There is ample evidence that eels used in this study had been exposed to HVA at the eel farm before they arrived at our institute. No virus was isolated from 6 eels that were slaughtered $4 \mathrm{~d}$ after fishes had been placed in aquariums at our institute. Fishes harboured HVA, however, and some fishes released virus spontaneously after a lag period of $11 \mathrm{~d}$ or virus release was provoked by dexamethasone treatment. Compared with control fishes, in the experimental fishes virus was isolated earlier (on Day 2) and more reproducibly (from Days 4 to 10, and from gills and the liver-spleen-kidney organ pool) after injection with dexamethasone. This means that there was more virus shedding in the experimental group. Stress by transfer of fishes from the eel farm to aquariums at the institute and from disturbance by repeated sampling of the fishes may have caused recrudescence of HVA in some fishes of the control group. The finding of recrudescence of HVA by stress or dexamethasone treatment supports the idea that HVA can establish a latent state in eels, although latency in the strict sense has not been proved. Latency of herpesvirus in the strict sense means that there is no full expression of the virus genome and no production of infectious virus during the latent state (Roizman \& Sears 1996). However, the pattern of virus release from these eels after stress or dexamethasone treatment is similar to that observed after recrudescence of true latent herpesvirus infections (Sheffy \& Davies 1972, Van Oirschot \& Gielkens 1984).

The low $O D_{450}$ values measured in the first blood samples using an ELISA for HVA antibodies and the fast immune response after intraperitoneal or gill inoculation of HVA were further indications that these fishes had been exposed to HVA before. These previous infections will have protected fishes from clinical signs after a secondary infection by intraperitoneal or gill inoculation. For definite proof that low $\mathrm{OD}_{450}$ values measured in first blood samples were specific for HVA antibodies, we have to compare these results with $\mathrm{OD}_{450}$ values of blood sampled from eels that can be guaranteed free of HVA. M onitoring of more stocks of cultured eels to find one free of HVA is underway. The fast immune response after intraperitoneal or gill inoculation of HVA suggests a secondary response (Van M uiswinkel 1995). Fishes have a less well-developed immune system than mammals but may possess a secondary immune response mechanism characterised by a faster and more differentiated response after re-

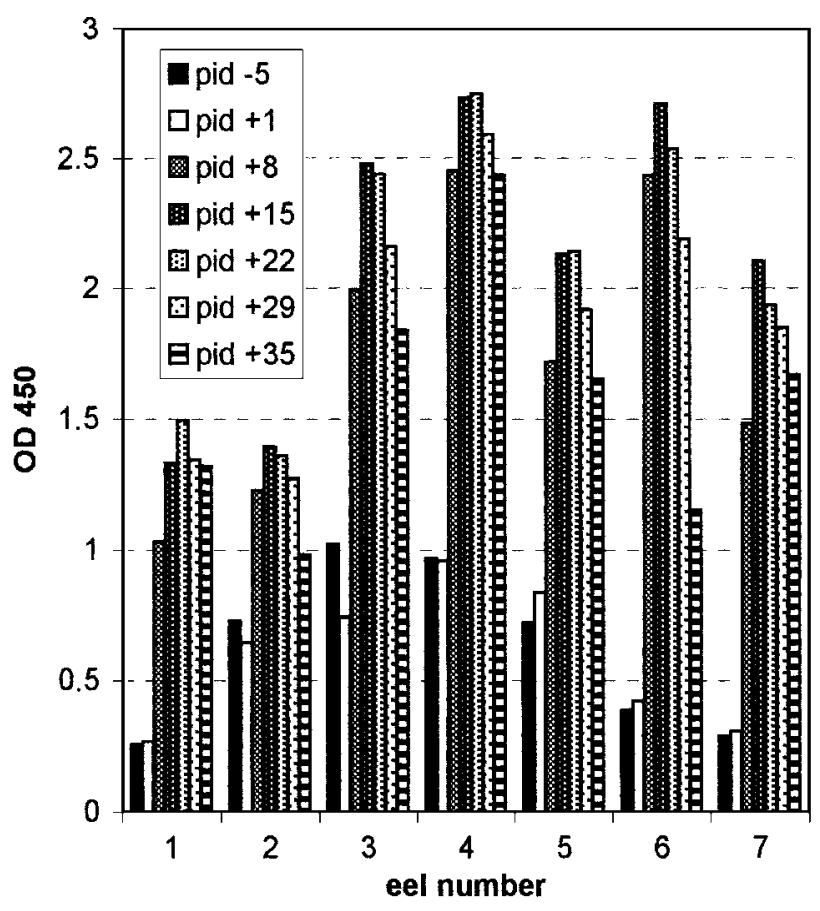

Fig. 2. Kinetics of the antibody response in 7 eels after intraperitoneal inoculation with HVA. $\mathrm{OD}_{450}$ of $1: 100$ dilutions of sera collected from $5 \mathrm{~d}$ before to $35 \mathrm{~d}$ after inoculation with HVA (post inoculation day [pid] -5 to +35 ) in an ELISA for HVA antibodies 
peated exposure to specific antigen (Kaattari \& Piganelli 1996).

A major characteristic of herpesviruses is their ability to persist and establish latency in the infected host. In this respect HVA of eel appeared no different from herpesviruses of mammals. The latent virus can be activated by exogeneous or endogeneous stimuli, and can subsequently be shed without clinical signs. Release of infectious virus from carrier fish can be provoked by treatment with dexamethasone. The procedure was used successfully in the present study to prove that eels from an outwardly healthy stock were infected with HVA. When stressed, carrier eels can release HVA. These fishes are a potential source of dissemination of HVA to non-immune glass eels and juvenile fishes, which are introduced 2 times a year from wild stock and cultured for replenishment of the standing stock. Further research to test this hypothesis about the origin of disease outbreaks caused by HVA infections among farmed eel is underway.

The high stocking density in recirculation systems with biofilters, which is common practice in eel farming in The Netherlands, supports the spread of HVA infections and complicates control of disease outbreaks once the virus has been introduced in an eel farm. A preliminary serological survey (results not shown) showed that HVA infections are common in stocks of cultured eel in The Netherlands. The best way to control disease outbreaks is to avoid the infection.

Although serological test procedures are not officially accepted for surveillance of fish populations previously exposed to a virus, serological techniques have been developed and used as epidemiological and diagnostic tools for many viral agents (LaPatra 1997). For example, serological screening has been conducted to assess the health status of trout farm populations for the rhabdoviruses that cause viral haemorrhagic septicaemia and infectious haemopoietic necrosis (Hattenberger-Baudouy et al. 1995). An ELISA test has recently been applied for selection of broodstock that is free of barfin flounder nervous necrosis virus (Watanabe et al. 2000). In the present study tools for tracing seropositive eel stocks that had previous contact with HVA virus and for tracing virus carriers that may disseminate the virus under certain circumstances were developed. These may be useful to control disease outbreaks caused by HVA among farmed eel.

Acknowledgements. We thank Dr J. H. W. M. Rombout from the Department of Cell Biology and Immunology of Wageningen University for making available monoclonal antibody WEI-1.

Editorial responsibility: J o-Ann Leong,

Corvallis, Oregon, USA

\section{LITERATURE CITED}

Bowser PR, M unson AD, J arboe $\mathrm{HH}$, Francis-Floyd R, Waterstrat FR (1985) Isolation of channel catfish virus from channel catfish, Ictalurus punctatus (Rafinesque), broodstock. J Fish Dis 8:557-561

Chen SN, Ueno Y, Kou GH (1982) A cell line derived from J apanese eel (Anguilla japonica). Proc Nat Sci Counc Rep China Pt B life Sci 6:93-100

Davidse A, Haenen OLM, Dijkstra SG, van Nieuwstadt AP, van der Vorst TJ K, Wagenaar F, Wellenberg GJ (1999) First isolation of herpesvirus of eel (Herpesvirus anguillae) in diseased European eel (Anguilla anguilla L) in Europe. Bull Eur Assoc Fish Pathol 19:137-141

Hattenberger-Baudouy AM, Danton M, Merle G, de Kinkelin $P$ (1995) Serum neutrilization test for epidemiological studies of salmonid rhabdoviruses in France. Vet Res 26: 512-520

Kaattari SL, Piganelli J D (1996) The specific immune system: humoral defense. In: Warma GI, Nakanishi T (eds) The fish immune system. Fish Physiol 15:207-254

LaPatra SE (1996) The use of serological techniques for virus surveillance and certification of finfish. Annu Rev Fish Dis 6:15-28

Lee NS, Kobayashi J , M iyazaki T (1999) Gill filament necrosis in farmed J apanese eel, Anguilla japonica (Temminck and Schlegel), infected with Herpesvirus anguillae. J Fish Dis 22:457-463

Pickering AD, Pottinger TG, Sumpter J P (1987) On the use of dexamethasone to block the pituitary-interrenal axis in the brown trout (Salmo trutta L.). Gen Comp Endocrinol 65:346- 353

Roizman B, Sears AE (1996) Herpes simplex viruses and their replication. In: Fields BN, Knipe DM, Howley PM (eds) Virology, 3rd edn. Lippincott-Raven Publishers, Philadelphia, p 2231-2295

Sano M, Fukuda H, Sano T (1990) Isolation and characterization of a new herpesvirus from eel. In: Perkins TO, Cheng TC (eds) Pathology in marine science, 3rd edn. A cademic Press, New York, p 15-31

Sheffy BE, Davies DH (1972) Reactivation of bovine herpesvirus after corticosteroid treatment. Proc Soc Exp Biol M ed 140:974-976

Van der Heijden MHT, Rooijakkers JBMA, Booms GHR, Rombout J HWM, Boon J H (1995) Production, characterization and applicability of monoclonal antibodies to European eel (Anguilla anguilla L. 1758) immunoglobulin. Vet Immunol Immunopathol 45:151-164

Van Muiswinkel WB (1995) The piscine immune system: innate and acquired immunity. In: Woo PTK (ed) Fish diseases and disorders, Vol 1. CAB International, Wallingford, $p$ 729-750

Van Oirschot J T, Gielkens ALJ (1984) In vivo and in vitro reactivation of latent pseudorabies virus in pigs born to vaccinated sows. Am J Vet Res 45:567-571

Watanabe K, Nishizawa T, Yoshimizu M (2000) Selection of brood stock candidates of barfin flounder using an ELISA system with recombinant protein of barfin flounder nervous necrosis virus. Dis Aquat Org 41:219-223

Whitley RJ (1996) Herpes simplex viruses. In: Fields BN, Knipe DM, Howley PM (eds) Virology, 3rd edn. Lippincott-Raven Publishers, Philadelphia, p 2297-2342

Submitted: October 18, 2000; Accepted: February 20, 2001 Proofs received from author(s): M ay 7, 2001 